\title{
STRATEGIC ANALYSIS OF THE DEVELOPMENT OF RENEWABLE ENERGETICS IN THE WORLD AND IN UKRAINE
}

\author{
VALENTYNA YAKUBIV, IRYNA BORYSHKEVYCH
}

\begin{abstract}
The article analyses tendencies in changes in power supply volumes in world countries for the last years. We identified tendencies in changes of power supply volumes in the context of different sources of its production. We studied the tendencies of development of renewable energetics in the world and in Ukraine. We based the potential of the development of renewable energetics in the world and in Ukraine. We conducted complex analysis of strategic perspectives of the development of renewable energetics in Ukraine on the basis of PEST-analysis. We also based the main trends of strategic changes in the industry in the framework of the most powerful external factors of influence the development of renewable energetics. We offered the complex of strategic measures within the limits of the most influential environmental factors within PESTanalysis.
\end{abstract}

Keywords: renewable energetics, strategic analysis, PEST-analysis, external factors, renewable sources of energy.

\section{INTRODUCTION}

European integration processes taking place in Ukraine presuppose the necessity of changes at different levels. In order to achieve expected positive results of European integration for Ukraine it is very important to adjust and participate in main economy-wide and social transformations that take place in European Union countries. In terms of that on the background of worldwide tendencies in changing power balance EU countries are developing quite rapidly. Quick pace of exhaustibility of world oil and gas supplies forces EU countries to develop renewable energetics. It is very important for Ukraine nowadays to establish active development of energy branch within the framework of world and European tendencies.

Renewable energetics is an important strategic niche of national economics of Ukraine able to affect energy security of the country, create new workplaces and ensure the growth of economic potential in general. Besides it plays an important role in development of gross domestic product. While investigating present state of the development of renewable energetics in Ukraine it is worth mentioning that this branch should be considered in the context of open system of cooperation with external factors. Under these conditions the enterprises associated with power generation with the aid of renewable sources should apply optimal, up-to-date management methods with the aim of their further adjustment to all external factors that are constantly changing. That is why it is necessary to 
conduct complex strategic analysis of the perspectives of the development in order to evaluate present state of the development of renewable energetics and forecast actions crucial for its further effective development.

Nowadays the perspectives and problems of the development of renewable energetics are studied by a lot of scholars as in the context of technological innovations for the development of this branch [1, $2,3]$, so as in the context of investigation economic and management preconditions of the establishment of renewable energetics $[4,5,6,7,8]$. At the same time strategic prerequisites of the development of the given branch have not been studied sufficiently, in particular external factors of influence the establishment perspectives of renewable energetics.

\section{RESULTS}

Rapid growth of world economics is accompanied by the increase of power consumption. Thus, according to the data from BP Statistical Review of World Energy power consumption has gone up for the last 10 years by 1922.8 Mtoe; the average power consumption volume increases annually by 1.0-1.9 $\%$. Just in 2017 world oil consumption increased by $1.9 \%$, natural gas - by $0.4 \%$, coal - by $1.8 \%$, nuclear fuel - by $1.6 \%$ [9].

According to the data from analytical sources world reserves of explored exhaustible energy sources will deplete in 40 years, the unexplored - in $10-50$ years at current power consumption pace. It is obvious that these negative tendencies forced developed world countries to intensify the development of energetics from renewable sources.

Within the last decade the renewable energetics has grown up in the world. Thus, in 2017 world amount of Total Primary Energy Supply (TPES) was 13.700 Mtoe (Figure 1).

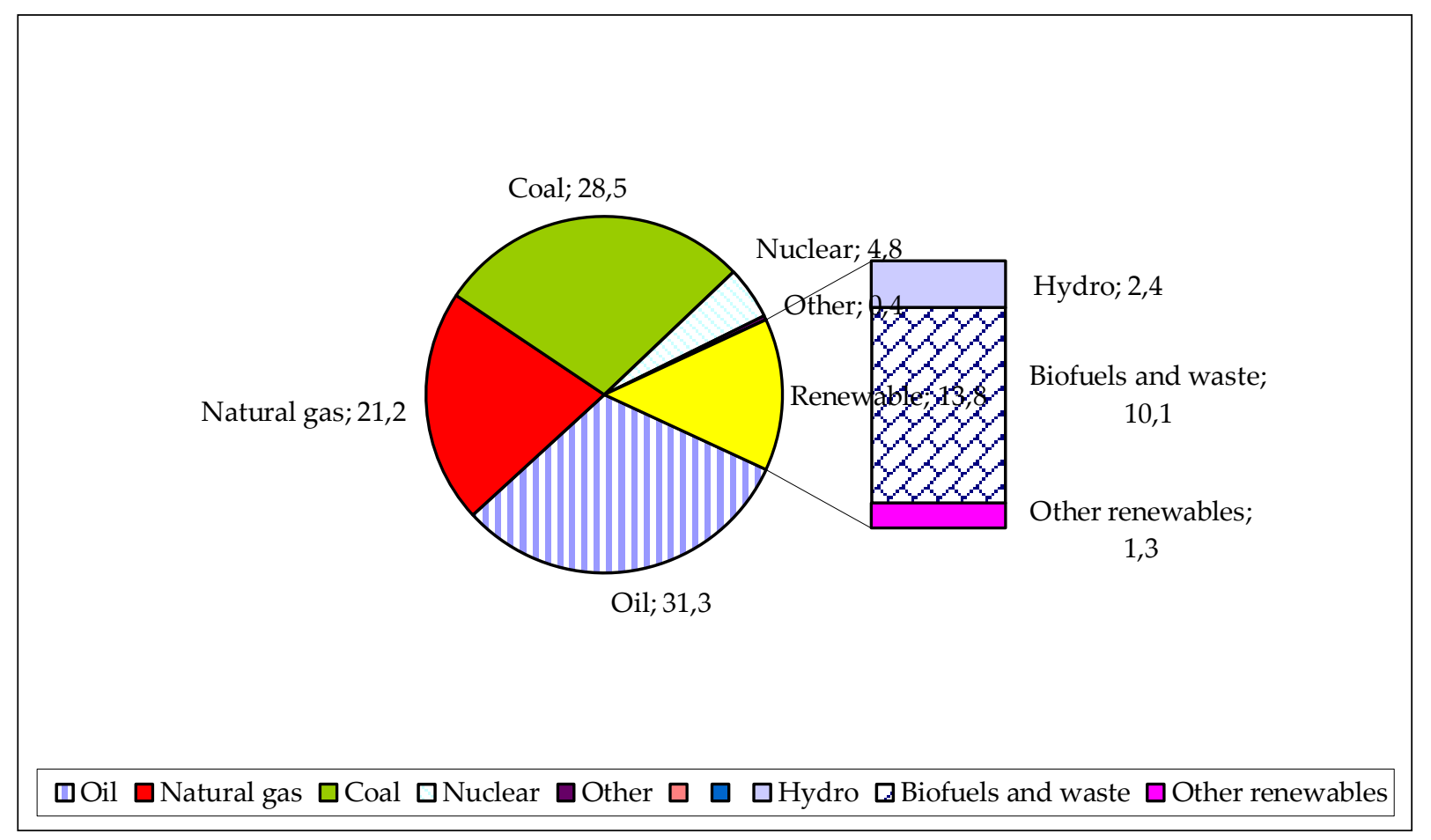

Fig. 1. Fuel shares in world total primary energy supply. *Source: [10].

Figure 1 describes that $13.8 \%$, or 1.894 Mtoe, was produced from renewable energy sources. The main components of renewable resources are: biofuels and waste, geothermal and wind resources (Figure 2). Since 1990, renewable energy sources have grown at an average annual rate of 2.2\%, which is slightly higher than the growth rate of world TPES, $1.9 \%$ [10]. 


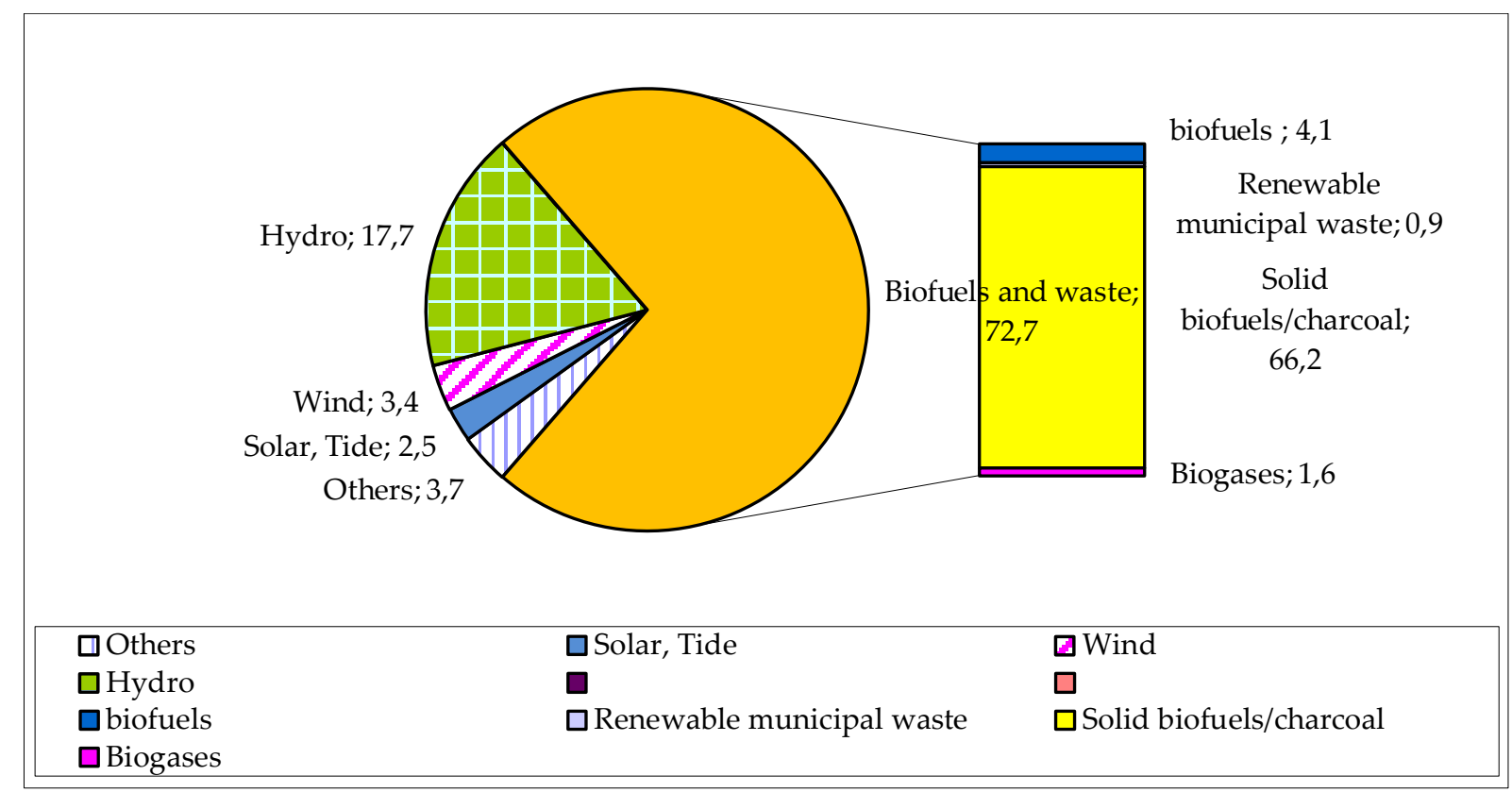

Fig. 2. Product shares in world renewable energy supply. *Source: [10].

During 1990 - 2017, renewable energy sources have grown at an average annual rate of 2.2\%, which is slightly higher than the growth rate of world TPES, it is $-1.9 \%$. The quickest growth rates of power generation from renewable sources was in the branch of solar energy, where production volumes has grown up by $46.2 \%$ for 15 years, wind energy - by $24.3 \%$, and bioenergetics - by $13.2 \%$.

While investigating the tendencies of development of renewable energetics in different world countries striking difference in tendencies and pace. Thus, there has been sustained tendency within the last years to active growth of the development of renewable energetics in the countries that are members of Organization for Economic Cooperation and Development (OECD). 34 countries are the members of OECD, namely: most European Union countries, the USA, Australia, Switzerland, Norway, South Korea, Japan and some others. These are developed countries with high human development index. At the same time we observe the growth of the gap between these countries and other countries in terms of energy production from renewable sources.

Ukraine has intensified power production processes from renewable sources for the last several years. Thus, within the period of 2015-2018 the capacity of renewable energetics objects (without taking into account temporarily occupied territory of AR Crimea), having "green" tariff has increased by 408 MW (from $967 \mathrm{MW}$ to $1375 \mathrm{MW}$ ), among them put into operation [10]:

1) in 2015 - $30 \mathrm{MW}$ of output;

2) in 2016-121 MW of output;

3) $2017-257 \mathrm{MW}$ of output.

As of the end of 2017 Ukraine has 376 operating objects of renewable energetics that have "green" tariff, with total output of $1375 \mathrm{MW}$, among them [10]:

1) 193 SPS with total output of $742 \mathrm{MW}$;

2) 20 WPS with total output of $465 \mathrm{MW}$;

3) 136 SHPS with total output of $95 \mathrm{MW}$;

4) 6 power biomass stations with total output of $39 \mathrm{MW}$;

5) 21 biogas power stations with total output of $34 \mathrm{MW}$.

Just in 2017 the objects of renewable energetics that have "green" tariff produced $2096 \mathrm{mln} \mathrm{kWh}$ of electrical power, among them: - $974 \mathrm{mln} \mathrm{kWh}$ by wind power stations; by solar power stations $715 \mathrm{mln} \mathrm{kWh}$; small hydropower stations - $212 \mathrm{mln} \mathrm{kWh}$; power biomass stations - $94 \mathrm{mln} \mathrm{kWh}$ (fig. 3). 


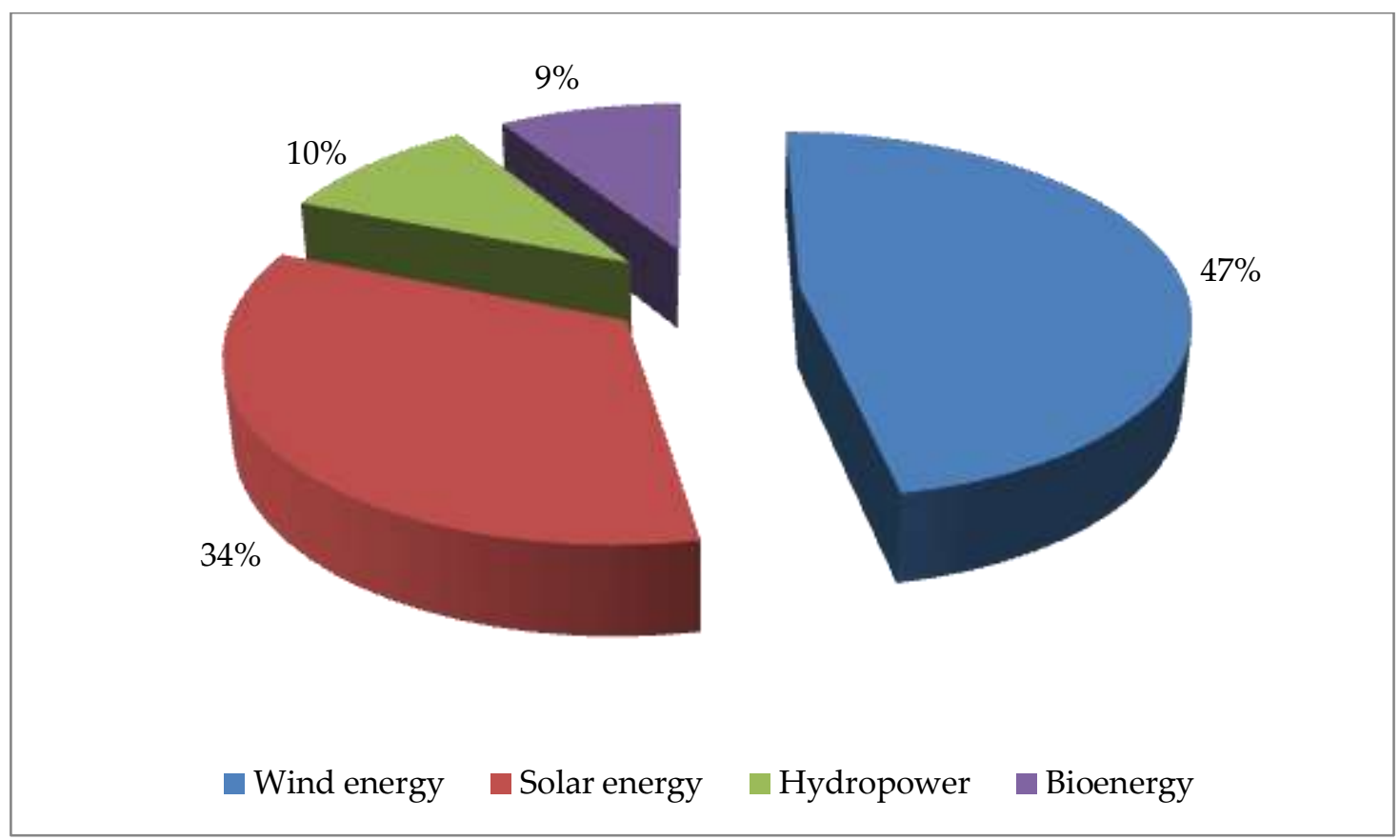

Fig. 3. Structure of production of renewable energetics in Ukraine in 2017. *Source: [11].

According to the data from Government agency on energy saving and power saving in Ukraine, Ukraine possesses considerable technically-achievable potential in production of energy sources from renewable sources of energy and alternative fuels that constitute over $98.0 \mathrm{mln} \mathrm{t}$ c.f. per year (table 1).

\begin{tabular}{|l|c|c|}
\hline \multirow{2}{*}{$\begin{array}{c}\text { Directions of exploration of } \\
\text { renewable energy sources }\end{array}$} & \multicolumn{2}{|c|}{$\begin{array}{c}\text { Annual technically-achievable } \\
\text { power potential }\end{array}$} \\
\cline { 2 - 3 } & $\begin{array}{c}\text { bln } \\
\text { kWh/year }\end{array}$ & $\begin{array}{c}\text { mln } \mathbf{t} \\
\text { c.f./year }\end{array}$ \\
\hline Wind power engineering & 79.8 & 28.0 \\
\hline Solar power & 38.2 & 6.0 \\
\hline Small hydropower & 8.6 & 3.0 \\
\hline Bio-energetics & 178 & 31.0 \\
\hline Geothermal power & 97.6 & 12.0 \\
\hline Environmental power & 146.3 & 18.0 \\
\hline $\begin{array}{l}\text { Overall volumes of substitution } \\
\text { of conventional energy sources }\end{array}$ & 548.5 & 98.0 \\
\hline
\end{tabular}

Tab. 1. Power potential from renewable sources in Ukraine. *Source: [12].

Taking into account the presence of positive tendencies in the development of renewable energetics in Ukraine and the potential of increase the volumes of this kind of production it is very important to investigate key factors that influence this process as from beneficial side so as from the negative one. That is why make reference to strategic analysis of internal factors that influence the prospects of the development of renewable energetics in Ukraine.

According to the statement of T. I. Dyoloh "strategic analysis - is the analysis of complex and dynamic set of factors that if generalized could be divided into inner primary and secondary, external basic, external immediate factors that in their complex unity influence the efficiency of the activities of an enterprise" [13, p. 47].

L. V. Nosonova defines strategic analysis as "the investigation of positive and negative factors that affect or may affect economic conditions of an enterprise in the future" [14, p. 548]. 
In terms of strategic analysis the evaluation of external and internal environment is conducted. External environment - is a set of political, economic, social, cultural, ethnical factors and the distinctions of its interconnection with partners, competitors, consumers, government bodies, mass media etc. The environment may not be affected by an enterprise or may be slightly affected. The internal environment, on the contrary is under immediate influence of the management of an enterprise.

Economics literature differentiates several tools of strategic analysis: PEST-analysis (the analysis of four groups of factors of macro environment: political, economic, socio-cultural and technological), SWOT-analysis (the analysis of weak and strong sides, possibilities and threats), strategic groups map (diagramed representation of the competition in the brunch), GE/McKinsey matrix (matrix "Attractiveness in the brunch / Position in competition"), Shell/DPM matrix (matrix of direct policy), PIMS-analysis (the analysis of the effect of market strategy on income) etc.

In order to analyze the key factors of external environment the world practice uses the technology of PEST-analysis. PEST-analysis (sometimes marked as -STEP) - is one of the tools of strategic analysis meant for defining political ( $\mathrm{P}$ - political: governmental stability, law-making and market regulations, fiscal policy, labor law), economical (E - economical: product design, interest rates, inflation rates, unemployment rate, salary rate, prices for energy sources and other production factors), social ( $\mathrm{S}-$ social-cultural: demographic tendencies, consumer habits, lifestyle, income distribution, education system) and technological ( $\mathrm{T}$ - technological: state and private investments into innovations and development, patent protection, technologies transmission rates) environmental aspects that influence the activities of enterprises [15, p. 142]. Each several factor is beyond the limits of direct control of the organization. While making an analysis it is necessary to define the factors that have the most effect on an enterprise and estimate them. Thus, external possibilities can be found that the enterprise should use and probable threats that should be avoided.

While conducting PEST-analysis one should remember that:

1) the analysis of strategic factors of each element should be systematic enough as in life all the components are interconnected;

2) the activities of any enterprise in external environment also depend on its own set of basic factors that influence its development the most.

The process of PEST-analysis can be conventionally divided into several stages:

1) defining factors for analysis that may affect sales and income of an enterprise in prospect of 3-5 years;

2) the estimating of the probability of factor change;

3) defining the level of factor;

4) defining windowed estimate of real weight of factors;

5) making-up summary table of PEST-analysis;

6) making-up final table of PEST-analysis.

Every next stage is closely connected to the previous one and complements it.

In order to estimate the probability of emerging factors of PEST-analysis and defining their level the experts in renewable energetics have been questioned as well as the scholars that investigate the problems of the development of this brunch.

System analysis of external environment factors of renewable energetics in Ukraine, their incidence and expert evaluation of the probability of factor change are generalized in table 2.

\begin{tabular}{|c|c|c|c|c|c|}
\hline & Factors description & $\begin{array}{c}\text { Success } \\
\text { rate } \\
\text { (amounting } \\
\text { to =1) }\end{array}$ & $\begin{array}{c}\text { Incidence } \\
\text { (from 1 to 5, where1 - } \\
\text { minimum success rate, } \\
5-\text { maximum })\end{array}$ & $\begin{array}{c}\text { Windowed } \\
\text { estimate }\end{array}$ \\
\hline $\mathbf{1}$ & $\mathbf{2}$ & $\mathbf{3}$ & $\mathbf{4}$ & $\mathbf{5}$ & $\mathbf{6}$ \\
\hline & 1. & $\begin{array}{c}\text { Stability of political power and present } \\
\text { government }\end{array}$ & 0.06 & 4 & 0.24 \\
\hline
\end{tabular}




\begin{tabular}{|c|c|c|c|c|c|}
\hline \multirow{9}{*}{ : } & 2. & $\begin{array}{l}\text { Positive changes in law in terms of } \\
\text { regulations of the activities of an } \\
\text { enterprise in renewable energetics } \\
\text { branch }\end{array}$ & 0.1 & 5 & 0.5 \\
\hline & 3. & $\begin{array}{l}\text { Positive changes in environmental } \\
\text { protection legislation }\end{array}$ & 0.09 & 4 & 0.36 \\
\hline & 4. & $\begin{array}{l}\text { Positive changes in competition and } \\
\text { labor legislation }\end{array}$ & 0.09 & 3 & 0.27 \\
\hline & 5. & $\begin{array}{l}\text { Positive changes in branch production } \\
\text { tools legislation }\end{array}$ & 0.07 & 4 & 0.28 \\
\hline & 6. & $\begin{array}{c}\text { State support intensification of } \\
\text { renewable energetics branch }\end{array}$ & 0.2 & 5 & 1.0 \\
\hline & 7. & $\begin{array}{l}\text { Qualitative and quantitative limitations } \\
\text { on export-import of energy (customs } \\
\text { system reorganization) }\end{array}$ & 0.07 & 4 & 0.28 \\
\hline & 8. & $\begin{array}{l}\text { Taxation policy reorganization (tariffs } \\
\text { relief and the increase of benefits) }\end{array}$ & 0.07 & 5 & 0.35 \\
\hline & 9. & $\begin{array}{l}\text { Elimination of red tape obstacles in } \\
\text { doing business }\end{array}$ & 0.1 & 4 & 0.4 \\
\hline & 10. & $\begin{array}{c}\text { Termination of military situation in the } \\
\text { country }\end{array}$ & 0.15 & 5 & 0.75 \\
\hline & & The incidence of political factors & 1.0 & $\mathrm{X}$ & 4.43 \\
\hline \multirow{11}{*}{ 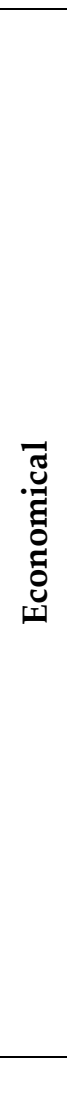 } & 1. & $\begin{array}{l}\text { Business climate improvement in the } \\
\text { country }\end{array}$ & 0.12 & 5 & 0.6 \\
\hline & 2. & $\begin{array}{l}\text { Activation of entrepreneur cooperation } \\
\text { with foreign partners }\end{array}$ & 0.11 & 4 & 0.44 \\
\hline & 3. & $\begin{array}{l}\text { The growth of investment attractiveness } \\
\text { of the country }\end{array}$ & 0.07 & 4 & 0.28 \\
\hline & 4. & $\begin{array}{l}\text { The growth of investment attractiveness } \\
\text { of the brunch }\end{array}$ & 0.12 & 5 & 0.6 \\
\hline & 5. & $\begin{array}{l}\text { Strengthening of competitive positions } \\
\text { and pressure reduction from the } \\
\text { competitors side }\end{array}$ & 0.09 & 5 & 0.45 \\
\hline & 6. & $\begin{array}{c}\text { Stabilization of main currencies } \\
\text { exchange rate }\end{array}$ & 0.08 & 4 & 0.32 \\
\hline & 7. & $\begin{array}{l}\text { Banning inflation processes which } \\
\text { complicate exchange of commodities } \\
\text { with foreign partners }\end{array}$ & 0.07 & 4 & 0.28 \\
\hline & 8. & $\begin{array}{l}\text { Reduction of interest rates on credits in } \\
\text { national currency }\end{array}$ & 0.06 & 3 & 0.18 \\
\hline & 9. & $\begin{array}{l}\text { The increase of investments attraction } \\
\text { volumes to power engineering branch }\end{array}$ & 0.13 & 5 & 0.65 \\
\hline & 10. & $\begin{array}{c}\text { Strengthening of export-import } \\
\text { operations with European countries }\end{array}$ & 0.15 & 4 & 0.6 \\
\hline & & The incidence of economic factors & 1.0 & $X$ & 4.4 \\
\hline \multirow{3}{*}{ 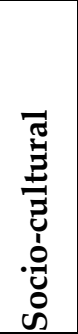 } & 1. & $\begin{array}{l}\text { Improvement of population income rate } \\
\text { (purchasing power) }\end{array}$ & 0.1 & 4 & 0.4 \\
\hline & 2. & $\begin{array}{l}\text { Increase in population growth, increase } \\
\text { in energy demand }\end{array}$ & 0.1 & 3 & 0.3 \\
\hline & 3. & $\begin{array}{c}\text { Relaxation of migration processes, } \\
\text { namely migration of high qualified } \\
\text { personnel } \\
\end{array}$ & 0.08 & 5 & 0.4 \\
\hline
\end{tabular}




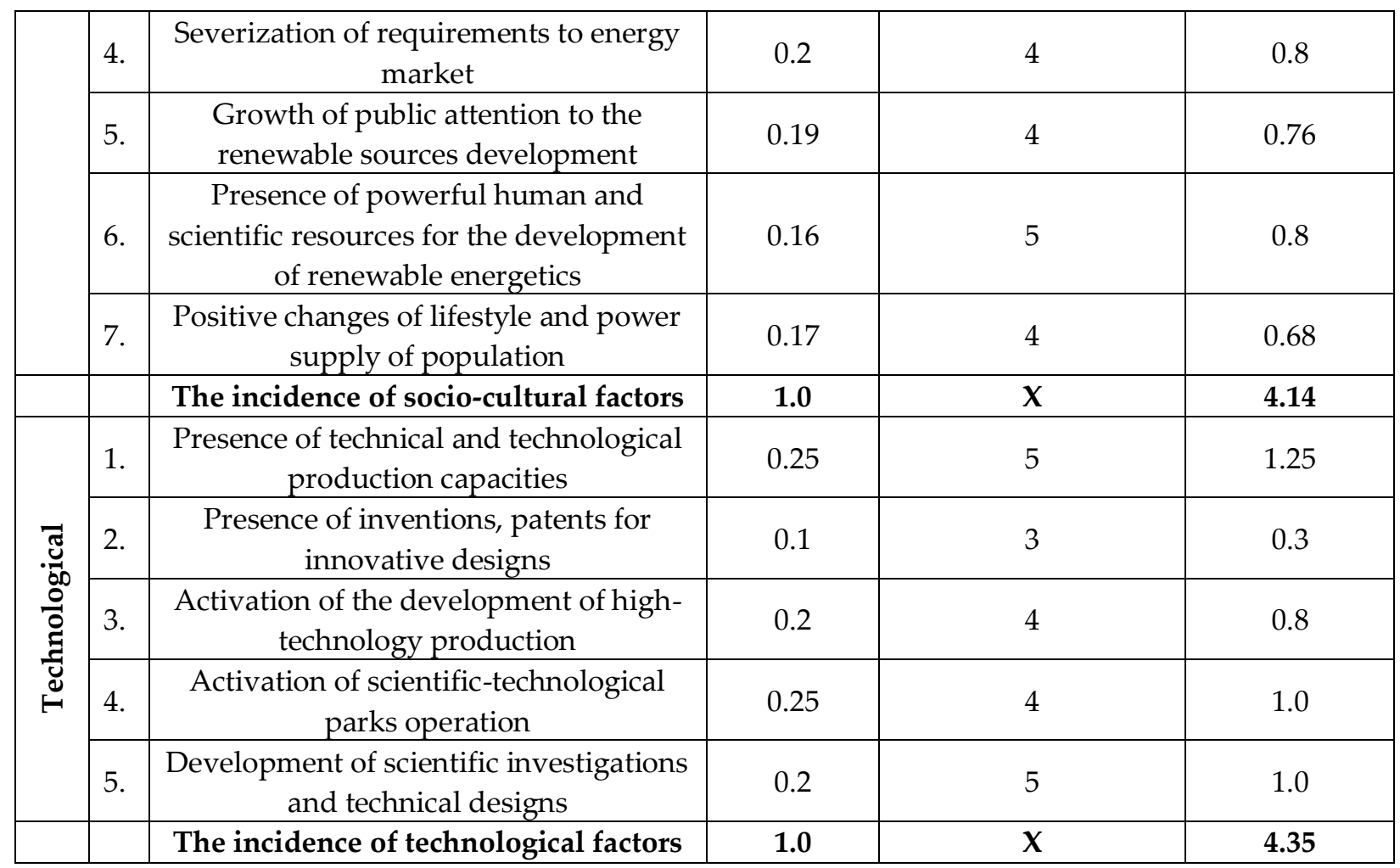

Tab. 2. PEST-analysis of the perspectives of development of renewable energetics in Ukraine. * Source: personal investigations of authors.

The conducted analysis showed that the perspectives of the development of renewable energetics in Ukraine principally depend on political factors (influence coefficient 4.4). Technological and sociocultural factors play somewhat less part (influence coefficients 4.35 and 4.14 respectively).

Let us summarize the most valuable factors according to the descending rating into summary table (table 3).

\begin{tabular}{|c|c|c|c|}
\hline \multicolumn{2}{|c|}{ Factors } & \multicolumn{2}{c|}{ Factors } \\
\hline $\begin{array}{c}\text { Political factors } \\
\text { renewable energetics brunch }\end{array}$ & 1.0 & $\begin{array}{c}\text { The increase of investments attraction } \\
\text { volume to power engineering branch }\end{array}$ & 0.65 \\
\hline $\begin{array}{c}\text { Termination of military situation in } \\
\text { the country }\end{array}$ & 0.75 & $\begin{array}{c}\text { The improvement of business climate in } \\
\text { the country }\end{array}$ & 0.6 \\
\hline $\begin{array}{c}\text { Positive changes in legislation in } \\
\text { terms of regulation of the activities of } \\
\text { enterprises in renewable energetics } \\
\text { branch }\end{array}$ & 0,5 & $\begin{array}{c}\text { The increase of investments attraction of } \\
\text { the branch }\end{array}$ & 0.6 \\
\hline $\begin{array}{c}\text { Elimination of red tape obstacles in } \\
\text { doing business }\end{array}$ & 0.4 & $\begin{array}{c}\text { Strengthening of export-import } \\
\text { operations with European countries }\end{array}$ & 0.6 \\
\hline $\begin{array}{c}\text { Positive changes in environmental } \\
\text { protection legislation }\end{array}$ & 0.36 & $\begin{array}{c}\text { Strengthening of competitive positions } \\
\text { and pressure reduction from the } \\
\text { competitors side }\end{array}$ & 0.45 \\
\hline Social-cultural factors & 0.8 & $\begin{array}{c}\text { Presence of technical and technological } \\
\text { production capacities }\end{array}$ & 1.25 \\
\hline $\begin{array}{c}\text { Severization of requirements to } \\
\text { energy market }\end{array}$ & 0.8 & $\begin{array}{c}\text { Activation of scientific-technological } \\
\text { parks operation }\end{array}$ & 1.0 \\
\hline $\begin{array}{c}\text { Presence of powerful human and } \\
\text { scientific resources for the } \\
\text { development of renewable energetics }\end{array}$ & & Technological factors \\
\hline
\end{tabular}




\begin{tabular}{|c|c|c|c|}
\hline $\begin{array}{c}\text { Growth of public attention to the } \\
\text { renewable sources development }\end{array}$ & 0.76 & $\begin{array}{c}\text { Development of scientific investigations } \\
\text { and technical designs }\end{array}$ & 1.0 \\
\hline $\begin{array}{c}\text { Positive changes of lifestyle and } \\
\text { power supply of population }\end{array}$ & 0.68 & $\begin{array}{c}\text { Activation of the development of high- } \\
\text { technology production }\end{array}$ & 0.8 \\
\hline $\begin{array}{c}\text { Improvement of population income } \\
\text { rate (purchasing power) }\end{array}$ & 0.4 & $\begin{array}{c}\text { Presence of inventions, patents for } \\
\text { innovative designs }\end{array}$ & 0.3 \\
\hline
\end{tabular}

Tab. 3. Summary table of PEST-analysis of the development of renewable energetics in Ukraine. * Source: personal investigations of authors.

Final step of the analysis is shaping all the calculations into matrix. All the factors are placed downwards according to their significance in the final PEST-analysis table (table 4).

\begin{tabular}{|c|c|c|}
\hline Factors & Changes in brunch & Strategic actions \\
\hline \multicolumn{3}{|c|}{ Political factors } \\
\hline $\begin{array}{l}\text { State support intensification of } \\
\text { renewable energetics branch }\end{array}$ & $\begin{array}{l}\text { The increase of business } \\
\text { profitability, expectable growth of } \\
\text { the number of enterprises }\end{array}$ & $\begin{array}{l}\text { Increase of production at the } \\
\text { cost of different governmental } \\
\text { programs and subventions }\end{array}$ \\
\hline $\begin{array}{l}\text { Termination of military } \\
\text { situation in the country }\end{array}$ & $\begin{array}{l}\text { Stabilization of doing business, } \\
\text { the increase of international } \\
\text { cooperation }\end{array}$ & $\begin{array}{l}\text { Finding international partners } \\
\text { and international expansion }\end{array}$ \\
\hline $\begin{array}{l}\text { Positive changes in legislation } \\
\text { in terms of regulation of the } \\
\text { activities of enterprises in } \\
\text { renewable energetics branch }\end{array}$ & $\begin{array}{l}\text { The increase of brunch } \\
\text { profitability and the volumes of } \\
\text { production }\end{array}$ & $\begin{array}{l}\text { The increase of social } \\
\text { responsibility level of } \\
\text { enterprises (namely in terms of } \\
\text { taxation), increase of wages }\end{array}$ \\
\hline $\begin{array}{l}\text { Elimination of red tape } \\
\text { obstacles in doing business }\end{array}$ & $\begin{array}{l}\text { Business environment } \\
\text { simplification for agricultural } \\
\text { enterprises }\end{array}$ & Following rules of fair business \\
\hline $\begin{array}{l}\text { Positive changes in } \\
\text { environmental protection } \\
\text { legislation }\end{array}$ & $\begin{array}{l}\text { Better level of environmental } \\
\text { protection }\end{array}$ & $\begin{array}{l}\text { Construction and operation of } \\
\text { sewage treatment plants, the } \\
\text { development of high } \\
\text { technologies, land erosion } \\
\text { control }\end{array}$ \\
\hline \multicolumn{3}{|c|}{ Economic factors } \\
\hline $\begin{array}{l}\text { The increase of investments } \\
\text { attraction volumes to power } \\
\text { engineering branch }\end{array}$ & $\begin{array}{l}\text { The increase of production } \\
\text { volumes and productive capacities }\end{array}$ & $\begin{array}{l}\text { Concentrating attention to the } \\
\text { quality, production of high } \\
\text { quality goods }\end{array}$ \\
\hline $\begin{array}{l}\text { Business climate improvement } \\
\text { in the country }\end{array}$ & $\begin{array}{l}\text { The increase of number of } \\
\text { agricultural enterprises }\end{array}$ & $\begin{array}{l}\text { Innovative development, } \\
\text { attraction of domestic and } \\
\text { foreign investments }\end{array}$ \\
\hline $\begin{array}{l}\text { The increase of investments } \\
\text { attraction volumes to power } \\
\text { engineering branch }\end{array}$ & $\begin{array}{l}\text { The increase of investments } \\
\text { earnings into branch }\end{array}$ & $\begin{array}{l}\text { Production quality upgrading, } \\
\text { build-up competitive benefits } \\
\text { in order to attract investments }\end{array}$ \\
\hline $\begin{array}{l}\text { Strengthening of export-import } \\
\text { operations with European } \\
\text { countries }\end{array}$ & $\begin{array}{l}\text { New possibilities for agricultural } \\
\text { enterprises }\end{array}$ & $\begin{array}{l}\text { Goods quality upgrading, } \\
\text { design of a new program of } \\
\text { product distribution }\end{array}$ \\
\hline $\begin{array}{l}\text { Strengthening of competitive } \\
\text { positions and pressure } \\
\text { reduction from the competitors } \\
\text { side }\end{array}$ & $\begin{array}{l}\text { The development of "healthy" } \\
\text { competition in the branch }\end{array}$ & $\begin{array}{l}\text { Finding ways to consolidate } \\
\text { positions in the branch }\end{array}$ \\
\hline \multicolumn{3}{|c|}{ Social-cultural factors } \\
\hline $\begin{array}{l}\text { Severization of requirements to } \\
\text { energy market }\end{array}$ & $\begin{array}{l}\text { The growth of amount of } \\
\text { competitive enterprises }\end{array}$ & $\begin{array}{l}\text { Upgrading products and } \\
\text { service level, boosting }\end{array}$ \\
\hline
\end{tabular}




\begin{tabular}{|c|c|c|}
\hline & & competitive positions \\
\hline $\begin{array}{l}\text { Presence of powerful human } \\
\text { and scientific resources for the } \\
\text { development of renewable } \\
\text { energetics }\end{array}$ & $\begin{array}{l}\text { The growth of number of } \\
\text { competitive enterprises }\end{array}$ & $\begin{array}{l}\text { Stimulating innovative } \\
\text { activities }\end{array}$ \\
\hline $\begin{array}{l}\text { Growth of public attention to } \\
\text { the renewable sources } \\
\text { development }\end{array}$ & $\begin{array}{l}\text { The increase of cost of energy } \\
\text { production from alternative } \\
\text { sources }\end{array}$ & $\begin{array}{l}\text { Concentrating attention at } \\
\text { cutting population costs at the } \\
\text { expense of power production } \\
\text { from alternative energy } \\
\text { sources }\end{array}$ \\
\hline $\begin{array}{l}\text { Positive changes of lifestyle and } \\
\text { power supply habits of } \\
\text { population }\end{array}$ & $\begin{array}{l}\text { Growth of attention to power } \\
\text { production from alternative } \\
\text { sources }\end{array}$ & $\begin{array}{l}\text { Promoting public awareness as } \\
\text { to the possibilities of power } \\
\text { production from alternative } \\
\text { sources }\end{array}$ \\
\hline $\begin{array}{l}\text { Improvement of population } \\
\text { income rate (purchasing } \\
\text { power) }\end{array}$ & Growth of branch profitability & $\begin{array}{l}\text { Growth of companies output } \\
\text { rate, variety growth }\end{array}$ \\
\hline \multicolumn{3}{|c|}{ Technological factors } \\
\hline $\begin{array}{l}\text { Presence of technical and } \\
\text { technological production } \\
\text { capacities }\end{array}$ & $\begin{array}{l}\text { Increase of output capacities of the } \\
\text { branch }\end{array}$ & $\begin{array}{l}\text { The use of technical and } \\
\text { technological capacities in } \\
\text { order to obtain maximum } \\
\text { possible production output }\end{array}$ \\
\hline $\begin{array}{l}\text { Activation of scientific- } \\
\text { technological parks operation }\end{array}$ & $\begin{array}{l}\text { Activation of innovative activities } \\
\text { of the branch }\end{array}$ & $\begin{array}{l}\text { Producing scientific-technical } \\
\text { ideas to raise competitiveness } \\
\text { of the enterprises }\end{array}$ \\
\hline $\begin{array}{l}\text { Development of scientific } \\
\text { investigations and technical } \\
\text { designs }\end{array}$ & Modernizing the branch & $\begin{array}{l}\text { The use of "smart programs", } \\
\text { modern IT-technologies }\end{array}$ \\
\hline $\begin{array}{l}\text { Activation of the development } \\
\text { of high-technology production }\end{array}$ & $\begin{array}{l}\text { Positive trends of the } \\
\text { development of the branch }\end{array}$ & $\begin{array}{l}\text { Upgrade of equipment, } \\
\text { technological advancement of } \\
\text { production }\end{array}$ \\
\hline $\begin{array}{l}\text { Presence of inventions, patents } \\
\text { for innovative designs }\end{array}$ & Modernizing the branch & $\begin{array}{l}\text { Design and implementation of } \\
\text { innovations into production } \\
\text { activities }\end{array}$ \\
\hline
\end{tabular}

Tab. 4. Final PEST-analysis table of the perspectives if development ofagricultural enterprises in Ivano-Frankivsk region. *Source: personal investigations of authors.

The conducted PEST-analysis testifies different impact level of the factors analyzed at perspectives of the development of renewable energetics in Ukraine. The owners of this business and potential investors should foremost pay their attention at those factors that are the most influential ones. Thus, we have defined the changes that are taking place within the branch under the influence of different significant factors and outlined strategic measures to be taken by the enterprises of this branch.

\section{CONCLUSION}

Thus, the conducted investigation proves that the world power consumption volumes are constantly increasing, which is caused by quick pace of the growth of production capabilities of different branches. On the background of quick exhaustibility of natural resources available for power generation the present state is getting acute year after year. It forced world countries to develop energy production from renewable sources. The most dynamic pace of development of renewable energetics is observed in the countries belonging to Organization of Economic Development and Cooperation (OECD), but it is obvious that other less developed countries (incl. Ukraine) possess the prerequisites 
for development of this perspective branch. According to the results of conducted PEST-analysis it has been defined that Ukraine has favorable conditions for the development of power production from alternative energy sources, but there exist some obstacles on the way of activation of this process. We have offered a set of certain strategic measures in order to overcome the barrier of changes in the branch of renewable energetics in terms of the most influential strategic environmental factors.

\section{REFERENCES}

[1] Prokopiv V.V., Nykyruy L.I., Voznyak O.M., Dzundza B.S., Horichok I.V., Yavorskyi Ya.S., Matkivskyi O.M., Mazur T.M. The Thermoelectric Solar Generator. Physics and Chemistry of Solid State, 18 (3) (2017), 372-375. doi: 10.15330/pcss.18.3.372-375

[2] Mamur H., Ahiska R. A review: Thermoelectric generators in renewable energy. International Journal of Renewable Energy Research (IJRER), 4 (1) (2014), 128-136.

[3] Liu W., Hu J., Zhang S., Deng M., Han C.G., Liu Y. New trends, strategies and opportunities in thermoelectric materials: a perspective. Materials Today. Physics, 1 (2017), 50-60. doi: 10.1016/j.mtphys.2017.06.001

[4] Timmons D., Harris J.M., Roach B. The Economics of Renewable Energy. Global Development And Environment Institute, Tufts University, Medford, 2014.

[5] Apergis N., Danuletiu D.C. Renewable energy and economic growth: Evidence from the sign of panel long-run causality. International Journal of Energy Economics and Policy, 4 (4) (2014), 578-587.

[6] Jacobsson S., Bergek A., Finon D., Lauber V., Mitchell C., Toke D., Verbruggen A. EU renewable energy support policy: faith or facts? Energy policy, 37 (6) (2009), 2143-2146. doi: 10.1016/j.enpol.2009.02.043

[7] Hurmak N., Yakubiv V. Efficiency of intermediary activity of agricultural enterprises: Methods and assessment indicators. Bulgarian Journal of Agricultural Science, 23 (5) (2017), 712-716.

[8] Yakubiv V., Zhuk O., Prodanova I. Model of Region's balanced agricultural development using the biomass energy potential. Economic Annals-XXI, 3-4 (1) (2014), 86-89. Available at: http://soskin.info/userfiles/file/2014/3-4_2014/1/Yakubiv_Zhuk_Prodanova.pdf

[9] BP Statistical Review of World Energy 2018. Available at: https://www.bp.com/content/dam/bp/en/corporate/pdf/energy-economics/statistical-review/bp-statsreview-2018-full-report.pdf

[10] Renewables 2018 Global Status Report. Available at: http://www.ren21.net/wpcontent/uploads/2018/06/17-8652_GSR2018_FullReport_web_final_.pdf

[11] Information on power and volumes of electricity production by renewable energy companies, which have a "green" tariff (as of December 31, 2014). Available at: http://saee.gov.ua/sites/default/files/IV\%202017.pdf (in Ukrainian)

[12] Potential of renewable energy sources in Ukraine. Available at: http://saee.gov.ua/uk/activity/vidnovlyuvana-enerhetyka/potentsial (in Ukrainian)

[13] Dyolog T.I. Strategic analysis of enterprise environment. Investytsiyi: praktyka ta dosvid, 15 (2013), $46-48$. Available at: http://nbuv.gov.ua/UJRN/ipd_2013_15_11 (in Ukrainian)

[14] Nosonova L.V. Determination of the level of strategic potential of machine-building enterprises. Economy and Society, 9 (2017), 547-555. (in Ukrainian)

[15] Koriniev V.L. Estimation and planning of financial activity of the enterprise. Derzhava ta Rehiony. Seriya: Ekonomika ta Pidpryyemnytstvo, 4 (2011), 142-146. (in Ukrainian)

[16] Wisz G., Nykyruy L., Yakubiv V., Hryhoruk I., Yavorskyi R. Impact of advanced research on development of renewable energy policy: Case of Ukraine (review). IJRER, 8 (4) (2018), 2567-2584. Available at: https://www.ijrer.org/ijrer/index.php/ijrer/article/view/8688 
Address: Valentyna Yakubiv, Iryna Boryshkevych, Vasyl Stefanyk Precarpathian National University, 57, Shevchenko Str., Ivano-Frankivsk, 76018, Ukraine.

E-mail: yakubiv.valentyna@gmail.com, ira.boryshkevych@gmail.com

Received: 07.08.2018; revised: 18.12.2018.

Якубів Валентина, Боришкевич Ірина. Стратегічний аналіз перспектив розвитку відновлювальної енергетики в світі та в Україні. Журнал Прикарпатського університету імені Василя Стефаника, 5 (3-4) (2018), 33-43.

У статті проаналізовано тенденції змін в обсягах споживання енергії в країнах світу за останні роки. Встановлено тенденції змін в обсягах споживання енергії в розрізі різних джерел ії виробництва. Досліджено тенденції розвитку відновлювальної енергетики в світі та в Україні. Оббрунтовано потенціал розвитку відновлювальної енергетики в Україні. Проведено комплексний аналіз стратегічних перспектив розвитку відновлювальної енергетики в Україні на основі застосування методу PEST-аналізу. Обгрунтовано основні тенденції стратегічних змін в галузі в межах найбільш впливових зовнішніх факторів впливу на розвиток відновдювальної енергетики. Запропоновано комплекс стратегічних дій в межах найбільш впливових факторів зовнішнього середовища в межах PEST-аналізу.

Ключові слова: відновлювальна енергетика, стратегічний аналіз, РEST-аналіз, зовнішні фактори, відновлювальні джерела енергії. 